\title{
Effectiveness of a Constructed Wetland in Reducing Phosphorus Inflow Loads from an Agricultural Catchment Area
}

\section{Pawel Skonieczek ${ }^{1}$, Szymon Kobus ${ }^{2 *}$, Andrzej Rochwerger ${ }^{2}$, Mirosław Nowakowski ${ }^{3}$, Łukasz Matyka ${ }^{4}$, Marcin Żurek ${ }^{3}$}

\author{
${ }^{1}$ National Water Holding Polish Waters, Poland \\ ${ }^{2}$ Department of Water Resources, Climatology and Environmental Management, \\ University of Warmia and Mazury in Olsztyn, Poland \\ ${ }^{3}$ Research Division in Bydgoszcz, Plant Breeding and Acclimatization Institute - National Research Institute, Poland \\ ${ }^{4}$ Krajowa Spółka Cukrowa S.A., Poland
}

Received: 25 July 2019

Accepted: 11 January 2020

\begin{abstract}
Reduction of phosphorus inflow loads and removing its residues is the main issue in protecting waters in rural areas, as by causing eutrophication it largely degrades the function of the aqueous environment [1]. The main sources of mobile phosphorus include water flowing from arable land, residential areas, farms, transport routes, and sewage treatment plants.

It is therefore necessary to seek new methods of further reducing mobile phosphorus concentrations in surface waters. In efforts to find new ways of effective utilization of existing objects in environmental protection, the role of small constructed wetlands in providing additional treatment to flowing waters has been examined. Such objects are of low depth, with intensive water exchange and mixing. These features play an important role in matter transformation. The intensity of biogenic absorption depends mainly on water pollution, ecological condition of the wetland, season of the year, inflowing contamination load and retention time [2].
\end{abstract}

Keywords: agricultural and afforested catchment areas, constructed wetland, source of phosphorus

\section{Introduction}

The chemical composition of substances dissolved in waters in agricultural and forest areas depends on the watershed geochemical background, the biological

*e-mail: szymon.kobus@uwm.edu.pl processes and the impact of human economic activities. In forest areas with only slight human economic impact, the geochemical background and phytocoenosis play a major role, whereas in agricultural areas the effect of geochemical background is added to the impact of agriculture and urban waste, which results in speeding up the water eutrophication processes. A particularly important role in eutrophication processes is played by phosphorus, as a factor in the minimum. Used in plant 
production, it enters waters where it contributes to the intensive growth of phytoplankton and macrophytes. Their unconsumed excess dies and decomposes, consuming oxygen in the process and thereby degrading the aqueous environment.

For several years, pollution in large rivers in Poland has stopped increasing; moreover, pollution in smaller rivers is decreasing, though more slowly, despite great efforts aimed at their protection. This is due to building sewage systems and connecting them to sewage treatment plants, which makes sewage management more orderly, but the pollution which used to be part of biological circulation now enter rivers and water bodies directly, though in smaller amounts. Small rivers are in particular danger as even a minor amount of a contaminant may result in grave deterioration of water quality. Neglecting water and sewage management in rural areas has led to the accumulation of contamination in soil and shallow underground waters, with the contaminants eventually moving to surface waters. This greatly reduces the effects of the sewage treatment plant construction program in rural areas. In order to improve sewage management and to protect waters from a harmful excess of biogenic elements, the various methods employed should include the natural biological, physical and chemical processes that take place in natural and constructed wetlands, which very effectively stimulate biological treatment of water [3-6].

The process of seeking new methods of effective utilization of existing objects in environmental protection involves examination of the role of small, shallow water bodies in the purification of the rivers and streams that flow into them. Objects of this type are usually shallow, with a low level of water mixing and a large part of the surface covered with vegetation. These are factors that play an important role in matter transformation. The intensity of reducing the content of biogenic elements, including phosphorus, depends mainly on water pollution, ecological condition of the water body, season of the year, amount of inflowing pollutants and retention time [7]. Each method of reducing the load of pollutants in surface waters is worth considering, especially if the investment outlays required are relatively small [8-9]. An important role can be played by objects that favor intensive growth of aqueous vegetation.

Higher plants have the ability to take up organic matter and use it in their metabolism or to accumulate it in their cells. According to many authors, macrophytes are the fundamental factor that regulate the water quality in wetlands, and the more of them there are, the more capable the wetlands are of self-purifying [10]. The good ability of macrophytes to purify water has encouraged practitioners to include marsh-simulating artificial systems in processes of purification of waste and waste-polluted waters. Natural treatment plants use the natural abilities of soil and plants of marsh ecosystem to retain and decompose contamination in water and sewage. The purification process is more efficient in artificial systems that simulate marsh ecosystems than in natural ones [11]. Purification of sewage from farmsteads and small rural communities is particularly important in terms of biogenic elements, including phosphorus. This is very important for improving the natural environment, including the quality of water in rivers, streams and water bodies [12-14]. Using small water bodies to reduce impurities load inflow results in their degradation. Those water bodies that are situated in urban watersheds and near farms are particularly susceptible to degradation.

The aim of our study was to determine the importance of a treatment wetland, situated on a small stream, for protecting a lake from degradation caused by inflow of pollutants and biogenic elements from agricultural areas. The study focused on determining the reduction of phosphorus concentration and load in the water of streams, the phosphorus inflowing from the sewage treatment plant and from agricultural areas, as well as its accumulation in the lake. The final section of the paper is devoted to another important issue: how the lake functions when the pollution load decreases after the sewage discharge from the sewage treatment plant to the stream is stopped.

\section{Materials and Methods}

Studies into the effectiveness of the constructed wetland as a place where phosphorus is reduced in protecting a lake from the inflow from an agricultural watershed were conducted in the years 2001-2007. A constructed wetland situated in the valley of the terminal section of the Sząbruk stream in northeastern Poland (in the macroregion of the Mazury Lake District, in the mesoregion of the Olsztyn Lake District) was chosen for detailed examination. The Sząruk stream watershed consists of a forest and agricultural part. The size of the Sząbruk stream watershed is $13.2 \mathrm{~km}^{2}$, including the forest part $\left(4.4 \mathrm{~km}^{2}\right)$, which accounts for $33 \%$ of the entire area (Fig. 1). There are two settlements within the area, Kolonia Uniszewo and Sząbruk, inhabited by ca. 600 people. During the initial part of the study (2001-2004) there were small sewage treatment plants operating there, which channeled the post-treatment water to the stream in question. There were three filter plots and two tanks in the area of the sewage treatment plant in Uniszewo. Sewage was received from 257 inhabitants. Sludge from this sewage treatment plant was transported by overflow and underground pipeline, fed the watercourse constantly. The sewage treatment plant in Sząbruk received sludge from 350 inhabitants. Sludge was aerated by the mixing device (Kessner's brush). Sewage treatment plant work was periodic and interrupted by two intermissions for clarification and realising sewage to the watercourse. In both cases, sludge had the same (existential and household) origin. After that time, in 2005, a sewage system was installed in the area and 


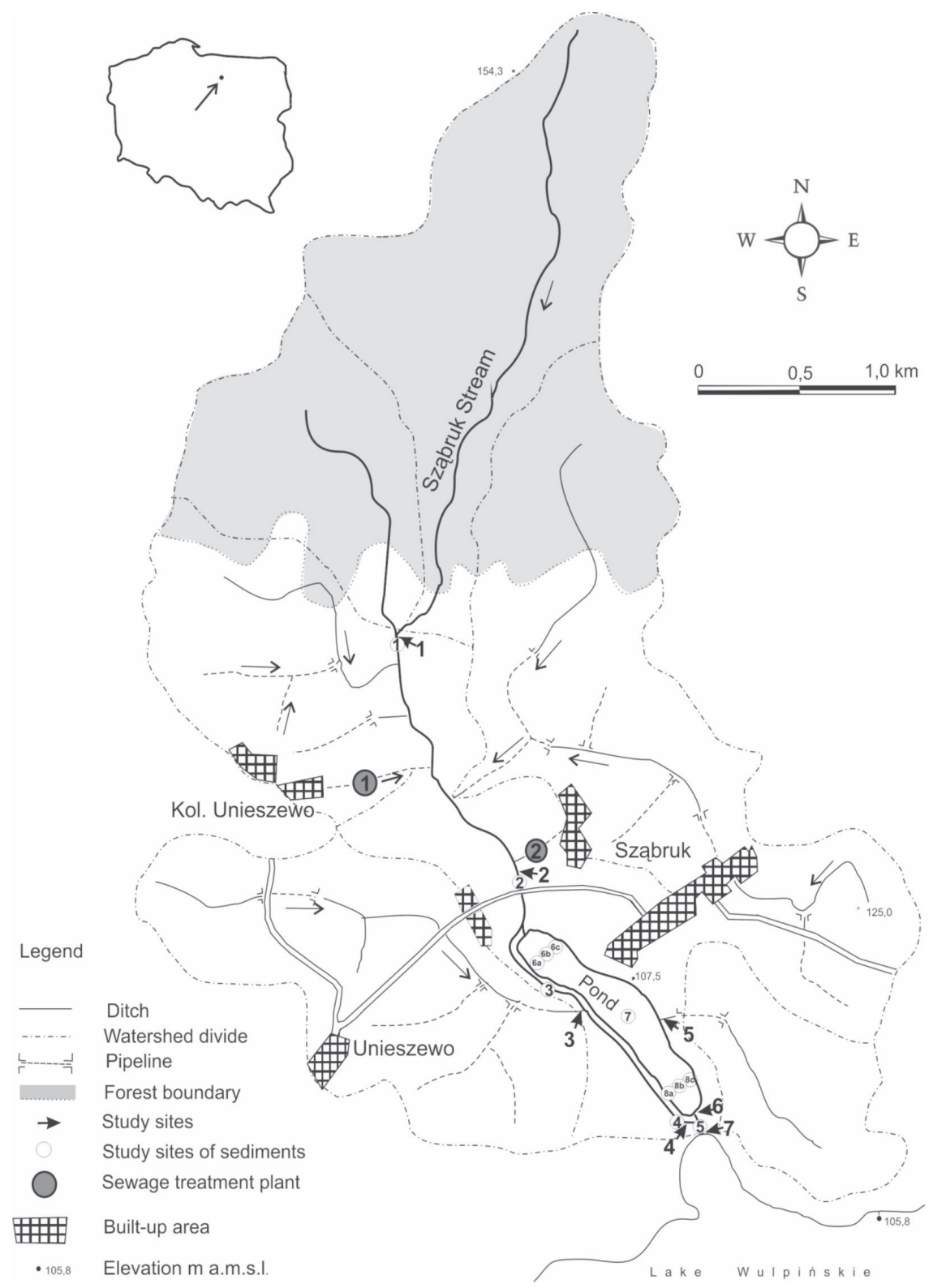

Fig. 1. Location of study sites in the watershed of Szabruk stream.

Study sites: 1) outflow from the forest watersheds; 2) before the constructed wetland; 2a) before the constructed wetland, 24-hour average; 3) inflow through the drain pipe to the surrounding ditch; 4) outflow from the surrounding ditch; 5) inflow through the drain pipe to the constructed wetland; 6) outflow from the constructed wetland; 7) outflow to the lake.

sewage was channeled to a new treatment plant outside the watershed.

In 1981 a $2.4 \mathrm{~m}$-high weir was built on the main stream, which created a storage reservoir of 24.8 ha. The water from the stream was divided into the reservoir and a drainage ditch. Ca. $61 \%$ of water from the Sząbruk stream flowed into the reservoir and the remaining part flowed through the ditch. After 25 years, $41.6 \%$ of the reservoir area had been covered by macrophytes, which made up rush communities with such dominant species as reed canary grass, common reed and broadleaf cattail, creating a specific "constructed wetland". In 2003 , ca. $90 \%$ of its bottom was covered by rigid hornwort (Ceratophyllum demersum L. s. str.), which made up Ceratophylletum demersi.
Water samples were taken in the stream watershed from the water flowing into the stream from the forest, along drain pipes from the agricultural area and outflowing from the treatment plant once a month. Samples of sediment deposits and littoral vegetation were also taken. During monthly sampling procedures, the water flow rate was measured with an electromagnetic flow meter. Samples of water for analysis were taken at seven study sites (Fig. 1). The plant and deposit sampling sites are shown in Fig. 2.

Flow measurement revealed that part of the water from the pond seeped through to the surrounding ditch where increased flow was recorded; therefore, a final reduction assessment was performed for the entire object. 


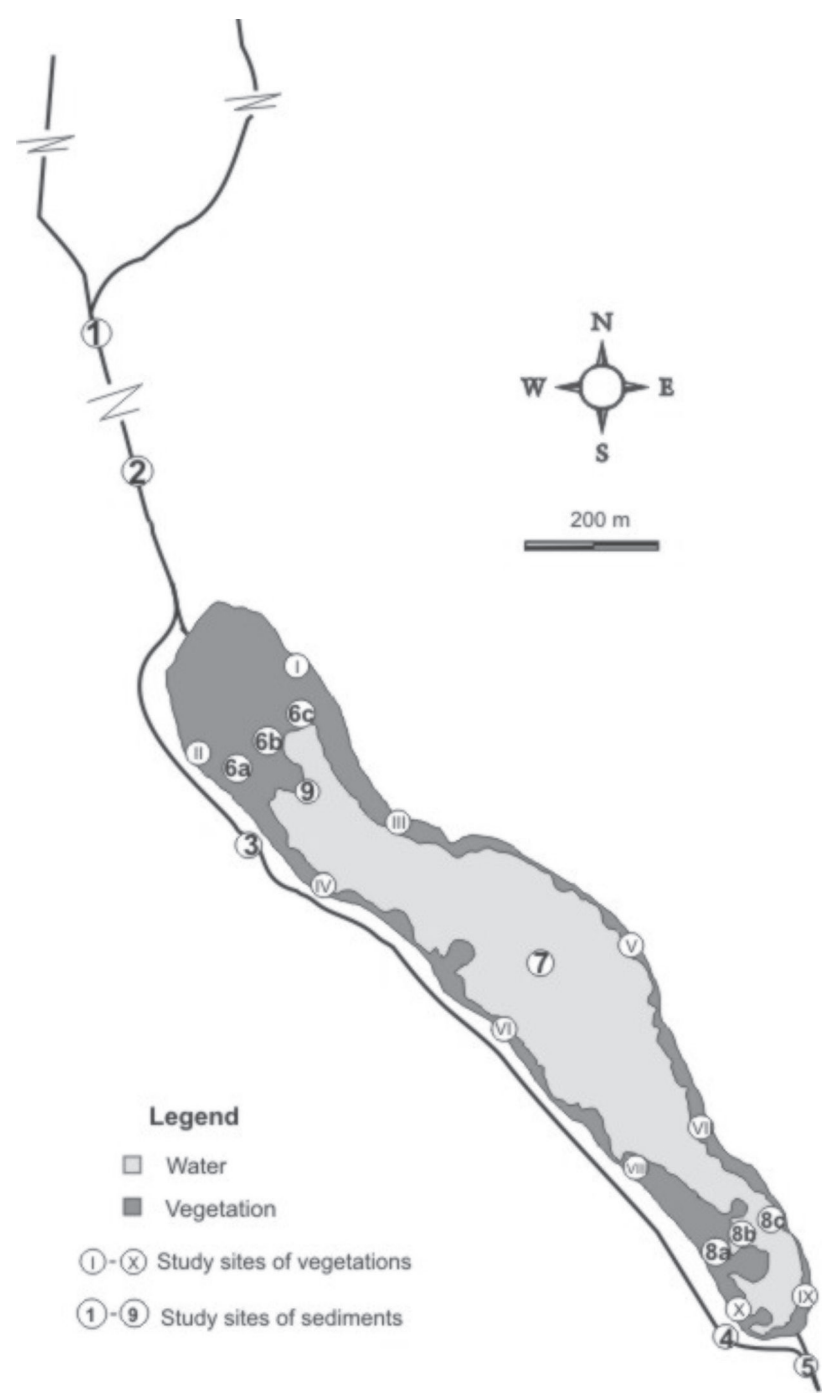

Fig. 2. Location of the bottom deposits and vegetation sample taking.

The water flow in the Sząbruk stream was highly variable. In general, an increase in the amount of flowing water occurred during a period of spring thaw. The pond can play the role of an outflow regulator as it reduces rapid flow fluctuations due to its structure; it can also receive large amounts of water and release it with a delay.

The average water flow at individual flow measurement sites varied throughout the research period (Table 1).

Of the agricultural watersheds, the highest inflow from a unit area was recorded during both study periods in the watershed, with the smallest area (82.4 ha - measurement site No. 5), the inflow from which was equal to $0.0044 \mathrm{~m}^{3} / \mathrm{s} \cdot \mathrm{km}^{2}$ during the first research period and $0.0038 \mathrm{~m}^{3} / \mathrm{s}^{2} \mathrm{~km}^{2}$ during the second one, which is close to the typical values for the Mazury Lake District. This watershed is specific not only because of its small area. There is a depression of a considerable size in it and water is channeled off through an underground pipeline directly to the constructed wetland. The least variable outflow per unit area was recorded for the forest drainage basins throughout the entire research period.

During the period of its operation, the treatment plant in Unieszewo supplied continuously $7.8 \mathrm{~m}^{3}$ of pre-treated sewage per 24 hours, i.e., $0.00009 \mathrm{~m}^{3} / \mathrm{s}$. The amounts did not cause the flow to increase significantly. The treatment plant in Sząbruk discharged $25 \mathrm{~m}^{3}$ of pre-treated sewage each time on average, i.e., $0.00029 \mathrm{~m}^{3} / \mathrm{s}$. The sewage was discharged twice within 24 hours for 30 minutes. It entered to the intermediate ditch, which greatly extended the time of inflow of the pre-treated sewage to Sząbruk stream. This prevented any increased flow in the stream and caused the sewage to dilute, which favored its purification. The total inflow of pre-treated sewage from both treatment plants to Sząbruk stream amounted to ca. $58 \mathrm{~m}^{3} \cdot 24 \mathrm{~h}^{-1}$.

The main sewage inflow from the treatment plant in Sząbruk to the stream was before the culvert, which corresponds to flow measurement site No. 2. Taking into account the water flow in the stream at the site during the period of the treatment plant operation of $0.0269 \mathrm{~m}^{3} / \mathrm{s}$ on average and the duration of the discharge period and the amount of sewage, it was determined that the proportion of sewage in average instantaneous flow was $2.5 \%$, whereas at the time of sewage discharge, sewage accounted for $33 \%$ of the flow.

The following were determined in samples of water, plants and bottom deposits: $\mathrm{P}_{\text {tot. }}$ (following mineralization) and $\mathrm{P}_{-} \mathrm{PO}_{4}$ colorimetrically with ammonium molybdenate and tin (II) chloride. The determinations were performed according to the generally approved methods [9].

Basic statistical calculations of minimum, maximum and mean values, as well as standard deviation (SD) were made. To assess the statistical differences among sampling locations for water quality data and environmental data (seasons and flows), a nonparametric analysis of the variance Kruskal-Wallis (K-W) was performed using STATISTICA 13.3 PL software.

\section{Results and Discussion}

The supply of $\mathrm{P}_{\text {tot. }}$ and $\mathrm{P}_{-} \mathrm{PO}_{4}{ }^{3-}$ was determined in the water inflowing from the forests, agricultural areas and at the outflow from the pond, and from the surrounding ditch and after they join before the outlet to Lake Wulpińskie (Table 2).

The study showed that the concentration of total phosphorus and phosphates, determined at various sections of Sząbruk stream, on the inlet and outlet from the constructed wetland and the surrounding ditch and the inlet to Lake Wulpińskie, was largely variable and depended on the nature and type of individual watersheds.

It is very difficult to observe the processes related to the flow of phosphate load through water due to its 
Table 1. Water flow in the object under study at individual study sites $\left[\mathrm{m}^{3} / \mathrm{s}\right]$.

\begin{tabular}{|c|c|c|c|}
\hline \multirow{2}{*}{ Study sites } & \multicolumn{2}{|c|}{ Flow } & Hydrological summer \\
\cline { 2 - 4 } & Hydrological year & Hydrological winter & 0.0126 \\
Outflow from forest watersheds (1) & $0.0141^{*}$ & 0.0151 & $0.0053-0.0241$ \\
\hline Outflow from agricultural and forest watersheds & $0.0053-0.0301^{* *}$ & $0.0104-0.0301$ & 0.0205 \\
(2) & 0.0267 & 0.0315 & $0.0234-0.0962$ \\
\hline Inflow through the drain pipe to the surrounding & $0.0234-0.1041$ & $0.0261-104.1$ & 0.0025 \\
ditch (3) & 0.0057 & 0.008 & $0.0009-0.0296$ \\
\hline Outflow from the surrounding ditch (4) & $0.0009-0.0383$ & $0.0067-0.0383$ & 0.0096 \\
& 0.0161 & 0.0213 & $0.001-0.0308$ \\
\hline Inflow through the drain pipe to the constructed & $0.001-0.683$ & $0.0126-0.0683$ & 0.0005 \\
wetland (5) & 0.0034 & 0.0052 & $0.000-0.007$ \\
\hline Outflow from the constructed wetland (6) & $0.0-0.0128$ & $0.0023-0.0128$ & 0.0056 \\
\hline Outflow to the lake (7) & 0.0072 & 0.0084 & $0.0003-0.0156$ \\
\hline
\end{tabular}

* average in the study period, ** min-max

Table 2. Content of $\mathrm{P}_{\text {tot }}$ and $\mathrm{P}_{-} \mathrm{PO}_{4}$ in the water of the watershed in question, carrying pollution from agricultural areas during the period of the treatment plant operation $[\mathrm{mg} / \mathrm{L}]$.

\begin{tabular}{|c|c|c|c|c|c|c|}
\hline \multirow{2}{*}{ Study site } & \multicolumn{3}{|c|}{$\mathrm{P}_{\text {tot }}$} & \multicolumn{3}{|c|}{$\mathrm{P}-\mathrm{PO}_{4}$} \\
\hline & $\begin{array}{l}\text { Hydrological } \\
\text { year }\end{array}$ & $\begin{array}{l}\text { Hydrological } \\
\text { winter }\end{array}$ & $\begin{array}{l}\text { Hydrological } \\
\text { summer }\end{array}$ & $\begin{array}{l}\text { Hydrological } \\
\text { year }\end{array}$ & $\begin{array}{l}\text { Hydrological } \\
\text { winter }\end{array}$ & $\begin{array}{l}\text { Hydrological } \\
\text { summer }\end{array}$ \\
\hline \multirow{2}{*}{$\begin{array}{l}\text { Outflow from forest } \\
\text { watersheds (1) }\end{array}$} & $\begin{array}{c}0.17^{*} \\
0.05 \div 0.31 * *\end{array}$ & $\begin{array}{c}0.20 \\
0.14 \div 0.31\end{array}$ & $\begin{array}{c}0.13 \\
0.05 \div 0.27\end{array}$ & $\begin{array}{c}0.13 \\
0.04 \div 0.23\end{array}$ & $\begin{array}{c}0.14 \\
0.07 \div 0.20\end{array}$ & $\begin{array}{c}0.12 \\
0.04 \div 0.23\end{array}$ \\
\hline & $\pm 0.07 * * *$ & \pm 0.05 & \pm 0.07 & \pm 0.04 & \pm 0.03 & \pm 0.05 \\
\hline \multirow{2}{*}{$\begin{array}{l}\text { Outflow from the } \\
\text { agricultural and forest } \\
\text { watershed ( } 2 \text { ) }\end{array}$} & $\begin{array}{c}0.28 \\
0.08 \div 0.52\end{array}$ & $\begin{array}{c}0.32 \\
0.18 \div 0.52\end{array}$ & $\begin{array}{c}0.25 \\
0.08 \div 0.45\end{array}$ & $\begin{array}{c}0.23 \\
0.04 \div 0.40\end{array}$ & $\begin{array}{c}0.23 \\
0.15 \div 0.35\end{array}$ & $\begin{array}{c}0.23 \\
0.04 \div 0.41\end{array}$ \\
\hline & \pm 0.107 & \pm 0.10 & \pm 0.11 & \pm 0.09 & \pm 0.07 & \pm 0.10 \\
\hline \multirow{2}{*}{$\begin{array}{l}\text { Before the wetland, 24- } \\
\text { hour average (2a) }\end{array}$} & $\begin{array}{c}0.42 \\
0.08 \div 0.82\end{array}$ & $\begin{array}{c}0.51 \\
0.347 \div 0.82\end{array}$ & $\begin{array}{c}0.34 \\
0.08 \div 0.58\end{array}$ & $\begin{array}{c}0.37 \\
0.05 \div 1.73\end{array}$ & $\begin{array}{c}0.42 \\
0.20 \div 0.47\end{array}$ & $\begin{array}{c}0.33 \\
0.05 \div 1.73\end{array}$ \\
\hline & \pm 0.16 & \pm 0.14 & \pm 0.15 & \pm 0.32 & \pm 0.08 & \pm 0.45 \\
\hline \multirow{2}{*}{$\begin{array}{l}\text { Inflow through the drain } \\
\text { pipe to the surrounding } \\
\text { ditch (3) }\end{array}$} & $\begin{array}{c}0.25 \\
0.07 \div 1.36\end{array}$ & $\begin{array}{c}0.33 \\
0.13 \div 1.36\end{array}$ & $\begin{array}{c}0.14 \\
0.07 \div 0.39\end{array}$ & $\begin{array}{c}0.17 \\
0.05 \div 0.35\end{array}$ & $\begin{array}{c}0.21 \\
0.10 \div 0.35\end{array}$ & $\begin{array}{c}0.12 \\
0.05 \div 0.22\end{array}$ \\
\hline & \pm 0.29 & \pm 0.42 & \pm 0.09 & \pm 0.09 & \pm 0.08 & \pm 0.06 \\
\hline \multirow{2}{*}{$\begin{array}{l}\text { Outflow from the sur- } \\
\text { rounding ditch (4) }\end{array}$} & $\begin{array}{c}0.28 \\
0.03 \div 0.79\end{array}$ & $\begin{array}{c}0.34 \\
0.25 \div 0.79\end{array}$ & $\begin{array}{c}0.18 \\
0.03 \div 0.40\end{array}$ & $\begin{array}{c}0.25 \\
0.05 \div 0.65\end{array}$ & $\begin{array}{c}0.31 \\
0.17 \div 0.65\end{array}$ & $\begin{array}{c}0.16 \\
0.05 \div 0.32\end{array}$ \\
\hline & \pm 0.17 & \pm 0.15 & \pm 0.12 & \pm 0.14 & \pm 0.15 & \pm 0.10 \\
\hline \multirow{2}{*}{$\begin{array}{l}\text { Inflow through the drain } \\
\text { pipe to the wetland (5) }\end{array}$} & $\begin{array}{c}0.14 \\
0.04 \div 0.28\end{array}$ & $\begin{array}{c}0.16 \\
0.07 \div 0.25\end{array}$ & $\begin{array}{c}0.13 \\
0.04 \div 0.28 \\
\end{array}$ & $\begin{array}{c}0.12 \\
0.03 \div 0.35\end{array}$ & $\begin{array}{c}0.12 \\
0.04 \div 0.21\end{array}$ & $\begin{array}{c}0.11 \\
0.03 \div 0.35\end{array}$ \\
\hline & \pm 0.08 & \pm 0.08 & \pm 0.08 & \pm 0.09 & \pm 0.07 & \pm 0.10 \\
\hline \multirow{2}{*}{$\begin{array}{l}\text { Outflow from the wet- } \\
\text { land (6) }\end{array}$} & $\begin{array}{c}0.34 \\
0.04 \div 0.75\end{array}$ & $\begin{array}{c}0.41 \\
0.25 \div 0.69\end{array}$ & $\begin{array}{c}0.29 \\
0.04 \div 0.75\end{array}$ & $\begin{array}{c}0.23 \\
0.03 \div 0.67\end{array}$ & $\begin{array}{c}0.28 \\
0.03 \div 0.67\end{array}$ & $\begin{array}{c}0.19 \\
0.03 \div 0.42\end{array}$ \\
\hline & \pm 0.21 & \pm 0.18 & \pm 0.22 & \pm 0.18 & \pm 0.23 & \pm 0.12 \\
\hline \multirow[t]{2}{*}{ Outflow to the lake (7) } & $\begin{array}{c}0.30 \\
0.06 \div 0.71\end{array}$ & $\begin{array}{c}0.35 \\
0.24 \div 0.71\end{array}$ & $\begin{array}{c}0.23 \\
0.06 \div 0.58\end{array}$ & $\begin{array}{c}0.24 \\
0.04 \div 0.56\end{array}$ & $\begin{array}{c}0.29 \\
0.16 \div 0.56\end{array}$ & $\begin{array}{c}0.17 \\
0.04 \div 0.39\end{array}$ \\
\hline & \pm 0.18 & \pm 0.14 & \pm 0.17 & \pm 0.14 & \pm 0.16 & \pm 0.11 \\
\hline
\end{tabular}

$*$ average, $* * \min -\max , * * * \pm \mathrm{SD}$ 
complexity and fluctuations in time. The dynamics of the process are related to the variability of the factors that affect the inflow of external load and to the changes that take place inside the ponds.

\section{Effect of Reduced Phosphorus Concentration} in Water during the Period of Sewage Discharge from the Treatment Plant

Good-quality water was only found in the section of flow through the forest watershed. The water quality deteriorated in the section flowing through the cultivated land, with a strongly marked relationship between water quality and land use [15].

The lowest concentration of total phosphorus at all of the analyzed study sites was recorded in the watershed from which water flowed directly to the pond $-0.14 \mathrm{mg} / \mathrm{L}$ on average. Water outflowing from the forest area was relatively clean and contained $0.16 \mathrm{mg} / \mathrm{L}$ of the element. Its concentration at the site remained similar throughout the study period. After the stream flowed through the agricultural watershed, the concentration of phosphorus increased to $0.42 \mathrm{mg} / \mathrm{L}$ on average, which considerably affected the impurities discharged from the treatment plant.

Considerable reduction of phosphorus concentration was recorded after water had flowed through the constructed wetland - from $0.42 \mathrm{mg} / \mathrm{L}$ to $0.34 \mathrm{mg} / \mathrm{L}$ on average; much greater reduction was recorded during the hydrological summer as compared to the annual average and to the winter period, especially.

This can be compared to the data for water in Sząbruk stream after it had flowed through the surrounding ditch, where it contained $0.28 \mathrm{mg} / \mathrm{L}$ of phosphorus, with $0.34 \mathrm{mg} / \mathrm{L}$ during the hydrological winter and $0.18 \mathrm{mg} / \mathrm{L}$ outside the period. As a result of the mixing of water outflowing from the constructed wetland and the surrounding ditch, the average concentration of phosphorus in the water inflowing to Lake Wulpińskie was $0.30 \mathrm{mg} / \mathrm{L}$. A similar tendency was recorded for

\section{$P_{\text {tot }}$ load $\left[\mathrm{kg} \cdot \mathrm{year}^{-1}\right]$}

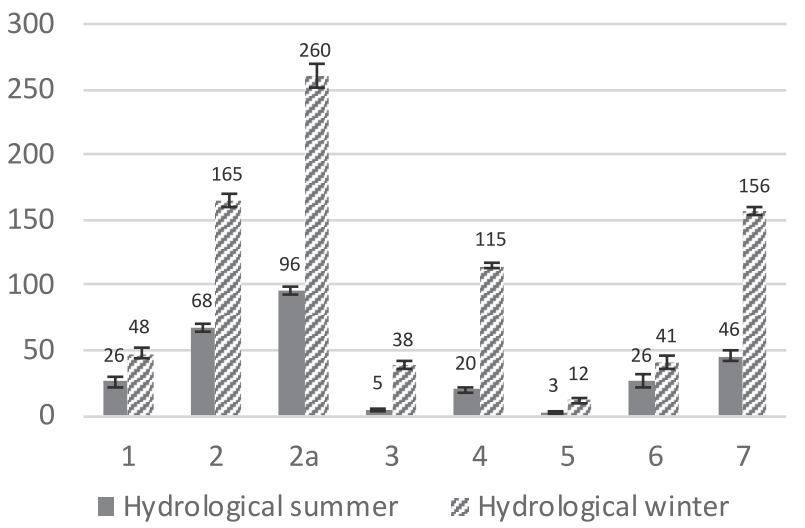

phosphate phosphorus, whose mean concentration in Sząbruk stream depended on the watershed type. Before being divided into the constructed wetland and the surrounding ditch, water contained $0.37 \mathrm{mg} / \mathrm{L}$ on average, and the concentration was 2.9 times higher than that recorded earlier, after the water flowed out of the forest. The average concentration of phosphorus was recorded to have decreased both in the constructed wetland and in the surrounding ditch. Agricultural use of individual watersheds with a drain system also seems to be of importance. With permanent covering of the water surface with vegetation, the average concentration of phosphorus at the drainage outlet was close to that in the water inflowing from the forest watershed.

Taking into account the average concentrations of total phosphorus and phosphate phosphorus and after calculating average flows in individual study sites, the annual phosphorus balance in different sections of Sząbruk stream was prepared (Fig. 3, Table 3). Measurements revealed that the waters of Sząbruk stream along the section from the (hydrological winter + hydrological summer) source to the site above the constructed wetland carried during a period of one year an average of $356 \mathrm{~kg} \mathrm{P}_{\text {tot }}$ 'year ${ }^{-1}$ and $309 \mathrm{~kg} \mathrm{P}-\mathrm{PO}_{4} \cdot$ year $^{-1}$. The forest watersheds supplied $74 \mathrm{~kg}_{\text {tot }}$.year ${ }^{-1}$ and $58 \mathrm{~kg} \mathrm{P}_{-} \mathrm{PO}_{4} \cdot$ year $^{-1}$. Agricultural watersheds supplied $159 \mathrm{~kg} \mathrm{P}$ tot ${ }^{\text {year }}{ }^{-1}$, including $132 \mathrm{~kg} \mathrm{P}-\mathrm{PO}_{4} \cdot$ year $^{-1}$; another $58 \mathrm{~kg}$ of phosphorus flowed through the drain pipes to the constructed wetland and to the surrounding ditch. $123 \mathrm{~kg} \mathrm{P}{ }_{\text {tot }}$ 'year ${ }^{-1}$, including $119 \mathrm{~kg} \mathrm{P}-\mathrm{PO}_{4} \cdot$ year $^{-1}$, flowed in from the treatment plant during the period of sewage discharge. Flow from the unit area of the watershed was very low - only $0.19 \mathrm{~kg} \mathrm{P}_{\text {tot }} \cdot$ ha $^{-1} \cdot$ year $^{-1}$. Phosphorus outflow from the agricultural area was found to have increased by $20 \%$ to $0.23 \mathrm{~kg} \mathrm{P}$ tot ha $^{-1} \cdot$ year $^{-1}$. Discharge from the sewage treatment plant accounted for ca. 30\% of the total phosphorus load (414 kg P.year ${ }^{-1}$ ), which resulted in an increase in phosphorus outflow from the watershed unit area.

\section{$\mathrm{P}-\mathrm{PO}_{4}$ load $\left[\mathrm{kg} \cdot\right.$ year $\left.^{-1}\right]$}

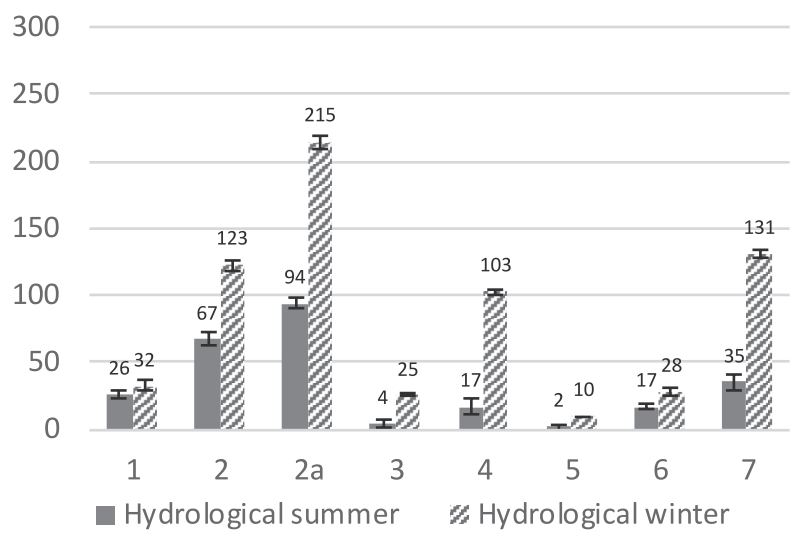

Fig. 3. Phosphorus compound loads at individual sites of the watershed during sewage discharge from the treatment plant. 1, 2, 2a, 3, 4, $5,6,7$ - study sites as in Table 2. 
Table 3. Balance of nutrients inflowing to the lake from Sząbruk stream watershed during sewage discharge from the treatment plant.

\begin{tabular}{|c|c|c|c|c|c|c|}
\hline & Item & Stream & $\begin{array}{l}\text { Draining } \\
\text { system }\end{array}$ & $\begin{array}{l}\text { Inflow to Lake } \\
\text { Wulpińskie }\end{array}$ & $\begin{array}{l}\text { Difference (reduction } \\
\text { in the wetland) }\end{array}$ & $\%$ reduction \\
\hline \multicolumn{7}{|c|}{$\mathrm{P}_{\text {tot }}$ load, $\mathrm{kg} \cdot$ year $^{-1}$} \\
\hline \multirow{2}{*}{$\begin{array}{l}\text { Hydrological } \\
\text { year }\end{array}$} & Without the wetland & $356 * \pm 5 * *$ & $58 \pm 3$ & $414 \pm 5$ & \multirow{2}{*}{212} & \multirow{2}{*}{51} \\
\hline & Including the wetland & $356 \pm 5$ & $58 \pm 3$ & $202 \pm 6$ & & \\
\hline \multirow{2}{*}{$\begin{array}{l}\text { Hydrological } \\
\text { winter }\end{array}$} & Without the wetland & $260 \pm 4$ & $50 \pm 4$ & $310 \pm 5$ & \multirow{2}{*}{154} & \multirow{2}{*}{49} \\
\hline & Including the wetland & $260 \pm 4$ & $50 \pm 4$ & $156 \pm 4$ & & \\
\hline \multirow{2}{*}{$\begin{array}{l}\text { Hydrological } \\
\text { summer }\end{array}$} & Without the wetland & $96 \pm 3$ & $8 \pm 1$ & $104 \pm 5$ & \multirow{2}{*}{58} & \multirow{2}{*}{56} \\
\hline & Including the wetland & $96 \pm 3$ & $8 \pm 1$ & $46 \pm 4$ & & \\
\hline \multicolumn{7}{|c|}{$\mathrm{P}-\mathrm{PO}_{4}$ load, kg $\cdot \mathrm{year}^{-1}$} \\
\hline \multirow{2}{*}{$\begin{array}{c}\text { Hydrological } \\
\text { year }\end{array}$} & Without the wetland & $309 \pm 5$ & $41 \pm 3$ & $350 \pm 9$ & \multirow{2}{*}{184} & \multirow{2}{*}{53} \\
\hline & Including the wetland & $309 \pm 5$ & $41 \pm 3$ & $166 \pm 6$ & & \\
\hline \multirow{2}{*}{$\begin{array}{l}\text { Hydrological } \\
\text { winter }\end{array}$} & Without the wetland & $215 \pm 6$ & $35 \pm 2$ & $250 \pm 4$ & \multirow{2}{*}{119} & \multirow{2}{*}{48} \\
\hline & Including the wetland & $215 \pm 6$ & $35 \pm 2$ & $131 \pm 6$ & & \\
\hline \multirow{2}{*}{$\begin{array}{l}\text { Hydrological } \\
\text { summer }\end{array}$} & Without the wetland & $94 \pm 4$ & $6 \pm 1$ & $100 \pm 5$ & \multirow{2}{*}{65} & \multirow{2}{*}{65} \\
\hline & Including the wetland & $94 \pm 4$ & $6 \pm 1$ & $35 \pm 3$ & & \\
\hline
\end{tabular}

* average, $* * \pm \mathrm{SD}$

The operation of a system consisting of the surrounding ditch and the constructed wetland resulted in supplying Lake Wulpińskie with $202 \mathrm{~kg} \mathrm{P}_{\text {tot }} \cdot$ year $^{-1}$ (reduction by $51 \%$ ) and $166 \mathrm{~kg} \mathrm{P}_{-} \mathrm{PO}_{4} \cdot$ year $^{-1}$ (reduction by $\mathrm{o} 53 \%$ ). A similar reduction of phosphorus concentration in waters flowing through shallow wetland was achieved by Schönbrunner et al., [6] in its high load with phosphorus from the watershed. The total phosphorus load outflowing from a unit watershed area was $0.15 \mathrm{~kg} \cdot \mathrm{ha}^{-1} \cdot \mathrm{year}^{-1}$. Balance specifications show the importance of such a system as a barrier intercepting considerable amounts of phosphorus flowing in from a watershed, especially during the vegetation period.

Phosphorus content in the biomass of littoral vegetation of the pond, which was determined twice during the period of the treatment plant operation, ranged from $0.14 \%$ to $0.44 \%$ of dry matter. Such a value of phosphorus concentration in dry matter is reported by Fernández-Aláez et al. [16]. The phosphorus content in the object under study varied from one study site to another, the difference between the lowest and the highest value being more than three orders of magnitude. The phosphorus content at various sites in 2003 was less varied than in 2004. Samples of vegetation taken near the inlet contained more $\mathrm{P}_{\text {tot. }}$ than those in the other parts of the wetland, where its amount decreased with increasing distance from the main source of supply. The $\mathrm{P}_{\text {tot. }}$ concentration was recorded to increase again in the terminal section of the pond, which was caused by inflow from the agricultural watershed. The pond vegetation accumulated $519 \mathrm{~kg} \mathrm{P}_{\text {tot. }}$ on twoyear average, which amounted to $50 \mathrm{~kg}$ per hectare (Table 4). The phosphorus accumulation in a warm year (2003) was found to be twice as high as in a normal year. The large accumulation of phosphorus in macrophyte biomass resulted from their optimum supply with easily available biogenic elements. Under favorable thermal conditions and with good solar exposure, they produced biomass with a high phosphorus content.

Unconsumed excess of biomass and the products of physicochemical processes of precipitation of substances from water fall to the bottom. The precipitating pollution and detritus produce bottom deposits, which constitute a specific "archive". Bottom particles bind both biogenic elements and heavy metals, which are among the most persistent toxic substances that enter aqueous ecosystems [17-19]. The process of sedimentation of particles, formation of a bottom layer and its consolidation depend on a number of factors that can be divided into the following categories: geomorphological, hydraulic, hydrodynamic and operational. A considerable effect on the process is exerted by the features of the solid particles (type of soil, size and shape of grains), their concentration, organic matter content and the presence of soluble salts in water.

The bottom deposit sampling sites are shown in Fig. 1. Bottom deposits varied in terms of their thickness and phosphorus content. The largest thickness was measured for the cores taken from the wetland center, whereas the smallest were those from the stream. There was an atypical bottom layer in the stream, which was different than those in other water bodies. The stream bottom is usually covered by coarse material, since fine particles are washed away, especially after increased flow and transported along the stream where they settle 
Table 4. Total P content in the overground biomass of the wetland vegetation [\% d.m.].

\begin{tabular}{|c|c|c|c|c|c|c|}
\hline \multirow{2}{*}{$\begin{array}{c}\text { Vegetation } \\
\text { sampling site }\end{array}$} & \multicolumn{3}{|c|}{ P content, in d.m. [\%] } & \multicolumn{2}{c|}{ P phytosorption in wetland vegetation biomass [kg] } \\
\cline { 2 - 7 } & 2003 & 2004 & Average & 2003 & 2004 & Average \\
\hline I & $0.27 * * \pm 0,01 * * *$ & $0.20 \pm 0,03$ & 0.24 & $125 \pm 5$ & $56 \pm 4$ & 91 \\
\hline II & $0.44 \pm 0,03$ & $0.34 \pm 0,08$ & 0.39 & $340 \pm 6$ & $119 \pm 3$ & 229 \\
\hline II & $0.25 \pm 0,02$ & $0.19 \pm 0,04$ & 0.22 & $21 \pm 3$ & $21 \pm 2$ & 21 \\
\hline IV & $0.26 \pm 0,03$ & $0.17 \pm 0,03$ & 0.22 & $38 \pm 3$ & $13 \pm 2$ & 26 \\
\hline V & $0.24 \pm 0,04$ & $0.28 \pm 0,05$ & 0.26 & $28 \pm 2$ & $15 \pm 2$ & 21 \\
\hline VI & $0.22 \pm 0,02$ & $0.14 \pm 0,05$ & 0.18 & $15 \pm 2$ & $16 \pm 3$ & 16 \\
\hline VII & $0.33 \pm 0,03$ & $0.28 \pm 0,02$ & 0.31 & $51 \pm 2$ & $19 \pm 3$ & 35 \\
\hline VIII & $0.22 \pm 0,02$ & $0.14 \pm 0,06$ & 0.18 & $67 \pm 2$ & $52 \pm 2$ & 59 \\
\hline IX & $0.20 \pm 0,03$ & $0.15 \pm 0,02$ & 0.18 & $8 \pm 1$ & $6 \pm 2$ & 7 \\
\hline X & $0.26 \pm 0,02$ & $0.32 \pm 0,04$ & 0.29 & $17 \pm 3$ & $11 \pm 2$ & 14 \\
\hline Entire wetland & & & & $710 \pm 2$ & $328 \pm 2$ & 519 \\
\hline
\end{tabular}

I - X - The vegetation sampling sites

* P phytosorption calculated for a vegetation area with a similar phytosociological composition

$* *$ average, $* * * \pm \mathrm{SD}$

when the flow rate decreases, i.e., when they meet resistance from vegetation or flowing through a water body [20].

The thickness of deposits in the stream did not exceed $10 \mathrm{~cm}$, whereas that in the pond was associated with its depth and was formed over the 25 years of the wetland's existence. The largest bottom thickness (up to $20 \mathrm{~cm}$ ) was recorded in the middle of the pond. The layer of bottom deposits thinned with the lake shallowing, which caused the $0-5-\mathrm{cm}$ thick layer to occupy an area of 11.9 ha. For this reason, the layer contained the largest load of phosphorus and other pollution [21].

An increase in phosphorus concentration in the bottoms was recorded below the sites with increased inflow abundant in the element, i.e., below the treatment plant in Sząbruk $1788 \mathrm{mg} \times \mathrm{kg}^{-1} \mathrm{~d} . \mathrm{m}$. and below the inflow from the agricultural watershed to the surrounding ditch $1395 \mathrm{mg} \times \mathrm{kg}^{-1}$ d.m. (Table 5). However, deposits on the pond bottom contained considerably less

Table 5. P content in the pond bottom deposits $\left[\mathrm{mg} \times \mathrm{kg}^{-1} \mathrm{~d} . \mathrm{m}\right.$.].

\begin{tabular}{|c|c|c|c|c|}
\hline No. & \multicolumn{2}{|c|}{ Sampling site } & in $0-10 \mathrm{~cm}$ layer & in $10-20 \mathrm{~cm}$ layer \\
\hline 1 & \multicolumn{2}{|c|}{ After the flows joined below the forest } & $218 * \pm 3 * *$ & - \\
\hline 2 & \multicolumn{2}{|c|}{ Below the treatment plant in Sząbruk } & $610 \pm 11$ & - \\
\hline 3 & \multicolumn{2}{|c|}{ Surrounding ditch } & $610 \pm 9$ & - \\
\hline 4 & \multicolumn{2}{|c|}{ End of surrounding ditch } & $1395 \pm 14$ & - \\
\hline 5 & \multicolumn{2}{|c|}{ After joining the pond outflow } & $1788 \pm 12$ & - \\
\hline \multirow{3}{*}{6} & \multirow{3}{*}{ Pond } & a & $1788 \pm 12$ & $785 \pm 11$ \\
\hline & & $\mathrm{b}$ & $1788 \pm 12$ & $1177 \pm 5$ \\
\hline & & $\mathrm{c}$ & $1177 \pm 12$ & $1003 \pm 10$ \\
\hline 7 & Pond & $\mathrm{b}$ & $1003 \pm 13$ & $785 \pm 12$ \\
\hline \multirow{3}{*}{8} & \multirow{3}{*}{ Pond } & $\mathrm{a}$ & $610 \pm 3$ & $610 \pm 3$ \\
\hline & & $\mathrm{b}$ & $610 \pm 3$ & $610 \pm 5$ \\
\hline & & $\mathrm{c}$ & $785 \pm 4$ & $610 \pm 4$ \\
\hline 9 & \multicolumn{2}{|c|}{ Deposit catcher } & \multicolumn{2}{|c|}{4491} \\
\hline
\end{tabular}

- No deposit * average, $* * \pm \mathrm{SD}$ 
phosphorus than those in the sedimentation phase (in the catcher). This is an effect of releasing phosphorus from the deposits on the pond bottom, from which a secondary release of phosphorus by mineralization and washing out takes place due to repeated contact with oxygenated water. Then a process of internal supply of water with phosphorus accumulated in the deposits is triggered. Bottom deposits in the wetlands where water is exchanged frequently contain lower concentrations of phosphorus [6]. Lower concentrations of phosphorus in the wetland under study were found in the bottom parts with quicker water flow and lower concentrations of dry matter. Ni and Wang [22] found a close relationship between the concentration of phosphorus and organic substance in bottom deposits. They also showed that older and deeper deposits are poorer in organic matter and phosphorus, which was also found in this paper. Precipitation of phosphorus compounds in the object under study was favored by considerable calcium concentration in water [23].

The mass of deposits accumulated in the pond was 2515 tons, which contained $2655 \mathrm{~kg}$ of $\mathrm{P}_{\text {tot. }}$, i.e., 101 tons of deposits accumulated in 1 ha of the pond bottom, containing $107 \mathrm{~kg}$ of phosphorus. The constructed wetland accumulated $0.4 \mathrm{~g} \mathrm{P} \mathrm{m}^{-2}$ year ${ }^{-1}$ A similar accumulation of phosphorus was shown by Johnston [4], whereas a study by Wang et al. [24] into the accumulation of phosphorus in deposits supplied with sewage showed phosphorus to accumulate at a rate of $30 \mathrm{~g} \mathrm{P} \mathrm{m}^{-2}$ year $^{-1}$.

\section{Effects of Reducing Phosphorus Content in Water during the Period When Sewage Discharge was Discontinued}

During the period after the sewage inflow from the treatment plant was discontinued, water from the forest area was of the highest quality $-0.16 \mathrm{mg} / \mathrm{L}$ $\mathrm{P}_{\text {tot }}$. Higher concentrations of total phosphorus (on average $0.27 \mathrm{mg} / \mathrm{L}$ ) were determined in Sząbruk stream above the reservoir of the water discharged from both the agricultural area and the forest. The highest concentrations of this element (on average $0.29 \mathrm{mg} / \mathrm{L}$ ) were found at the outflow from the drainage system that supplies the surrounding ditch and drains water from the agricultural crop field and in the outflow from the surrounding ditch (Table 6).

After the water flowed through the constructed wetland, the phosphorus concentration dropped to

Table 6. $\mathrm{P}_{\text {tot }}$ and $\mathrm{P}-\mathrm{PO}_{4}$ content in the waters of the watershed under study, which carried impurities from an agricultural area after sewage discharge from the treatment plant was discontinued $[\mathrm{mg} / \mathrm{L}]$.

\begin{tabular}{|c|c|c|c|c|c|c|}
\hline \multirow{2}{*}{ Study site } & \multicolumn{3}{|c|}{$\mathrm{P}_{\text {tot }}$} & \multicolumn{3}{|c|}{$\mathrm{P}_{-} \mathrm{PO}_{4}$} \\
\hline & $\begin{array}{l}\text { Hydrological } \\
\text { year }\end{array}$ & $\begin{array}{l}\text { Hydrological } \\
\text { winter }\end{array}$ & $\begin{array}{l}\text { Hydrological } \\
\text { summer }\end{array}$ & $\begin{array}{c}\text { Hydrological } \\
\text { year }\end{array}$ & $\begin{array}{l}\text { Hydrological } \\
\text { winter }\end{array}$ & $\begin{array}{l}\text { Hydrological } \\
\text { summer }\end{array}$ \\
\hline \multirow{2}{*}{$\begin{array}{l}\text { Outflow from forest water- } \\
\text { sheds (1) }\end{array}$} & $\begin{array}{c}0.16^{*} \\
(0.05 \div 0.28)^{* *}\end{array}$ & $\begin{array}{c}0.19 \\
(0.09 \div 0.28)\end{array}$ & $\begin{array}{c}0.12 \\
(0.05 \div 0.19)\end{array}$ & $\begin{array}{c}0.09 \\
(0.04 \div 0.14)\end{array}$ & $\begin{array}{c}0.10 \\
(0.06 \div 0.14)\end{array}$ & $\begin{array}{c}0.08 \\
(0.04 \div 0.13)\end{array}$ \\
\hline & $\pm 0.07 * * *$ & \pm 0.08 & \pm 0.06 & \pm 0.03 & \pm 0.03 & \pm 0.03 \\
\hline \multirow[t]{2}{*}{ Before the wetland ( $2 a)$} & $\begin{array}{c}0.27 \\
(0.09 \div 0.67) \\
\end{array}$ & $\begin{array}{c}0.30 \\
(0.9 \div 0.67)\end{array}$ & $\begin{array}{c}0.24 \\
(0.12 \div 0.38) \\
\end{array}$ & $\begin{array}{c}0.16 \\
(0.07 \div 0.46)\end{array}$ & $\begin{array}{c}0.17 \\
(0.07 \div 0.46)\end{array}$ & $\begin{array}{c}0.14 \\
(0.07 \div 0.32)\end{array}$ \\
\hline & \pm 0.17 & \pm 0.22 & \pm 0.10 & \pm 0.13 & \pm 0.16 & \pm 0.09 \\
\hline \multirow{2}{*}{$\begin{array}{l}\text { Inflow through the drain } \\
\text { pipe to the surrounding } \\
\text { ditch (3) }\end{array}$} & $\begin{array}{c}0.29 \\
(0.12 \div 0.55) \\
\end{array}$ & $\begin{array}{c}0.32 \\
(0.12 \div 0.55) \\
\end{array}$ & $\begin{array}{c}0.24 \\
(0.12 \div 0.45) \\
\end{array}$ & $\begin{array}{c}0.14 \\
(0.03 \div 0.34) \\
\end{array}$ & $\begin{array}{c}0.18 \\
(0.06 \div 0.34) \\
\end{array}$ & $\begin{array}{c}0.10 \\
(0.03 \div 0.20) \\
\end{array}$ \\
\hline & \pm 0.15 & \pm 0.17 & \pm 0.13 & \pm 0.03 & \pm 0.1 & \pm 0.1 \\
\hline \multirow{2}{*}{$\begin{array}{l}\text { Outflow from the sur- } \\
\text { rounding ditch (4) }\end{array}$} & $\begin{array}{c}0.29 \\
(0.17 \div 0.51) \\
\end{array}$ & $\begin{array}{c}0.32 \\
(0.17 \div 0.51) \\
\end{array}$ & $\begin{array}{c}0.25 \\
(0.17 \div 0.31) \\
\end{array}$ & $\begin{array}{c}0.11 \\
(0.04 \div 0.21)\end{array}$ & $\begin{array}{c}0.11 \\
(0.05 \div 0.21)\end{array}$ & $\begin{array}{c}0.10 \\
(0.04 \div 0.19)\end{array}$ \\
\hline & \pm 0.11 & \pm 0.14 & \pm 0.04 & \pm 0.06 & \pm 0.06 & \pm 0.06 \\
\hline \multirow{2}{*}{$\begin{array}{l}\text { Inflow through the drain } \\
\text { pipe to the wetland (5) }\end{array}$} & $\begin{array}{c}0.22 \\
(0.03 \div 0.40)\end{array}$ & $\begin{array}{c}0.24 \\
(0.07 \div 0.40) \\
\end{array}$ & $\begin{array}{c}0.20 \\
(0.03 \div 0.40) \\
\end{array}$ & $\begin{array}{c}0.08 \\
(0.01 \div 0.16)\end{array}$ & $\begin{array}{c}0.09 \\
(0.04 \div 0.16)\end{array}$ & $\begin{array}{c}0.06 \\
(0.01 \div 0.15)\end{array}$ \\
\hline & \pm 0.13 & \pm 0.12 & \pm 0.14 & \pm 0.05 & \pm 0.05 & \pm 0.06 \\
\hline \multirow{2}{*}{$\begin{array}{l}\text { Outflow from the wetland } \\
\qquad(6)\end{array}$} & $\begin{array}{c}0.16 \\
(0.06 \div 0.45) \\
\end{array}$ & $\begin{array}{c}0.20 \\
(0.08 \div 0.42) \\
\end{array}$ & $\begin{array}{c}0.13 \\
(0.06 \div 0.16) \\
\end{array}$ & $\begin{array}{c}0.04 \\
(0.01 \div 0.07) \\
\end{array}$ & $\begin{array}{c}0.04 \\
(0.02 \div 0.07) \\
\end{array}$ & $\begin{array}{c}0.03 \\
(0.01 \div 0.05) \\
\end{array}$ \\
\hline & \pm 0.11 & \pm 0.13 & \pm 0.04 & \pm 0.02 & \pm 0.02 & \pm 0.01 \\
\hline \multirow[t]{2}{*}{ Outflow to the lake (7) } & $\begin{array}{c}0.25 \\
(0.10 \div 0.46) \\
\end{array}$ & $\begin{array}{c}0.28 \\
(0.10 \div 0.46) \\
\end{array}$ & $\begin{array}{c}0.23 \\
(0.11 \div 0.29) \\
\end{array}$ & $\begin{array}{c}0.09 \\
(0.02 \div 0.19) \\
\end{array}$ & $\begin{array}{c}0.09 \\
(0.04 \div 0.19) \\
\end{array}$ & $\begin{array}{c}0.08 \\
(0.02 \div 0.18) \\
\end{array}$ \\
\hline & \pm 0.12 & \pm 0.14 & \pm 0.07 & \pm 0.05 & \pm 0.05 & \pm 0.06 \\
\hline
\end{tabular}

$*$ average, $* *$ min-max, $* * * \pm \mathrm{SD}$ 


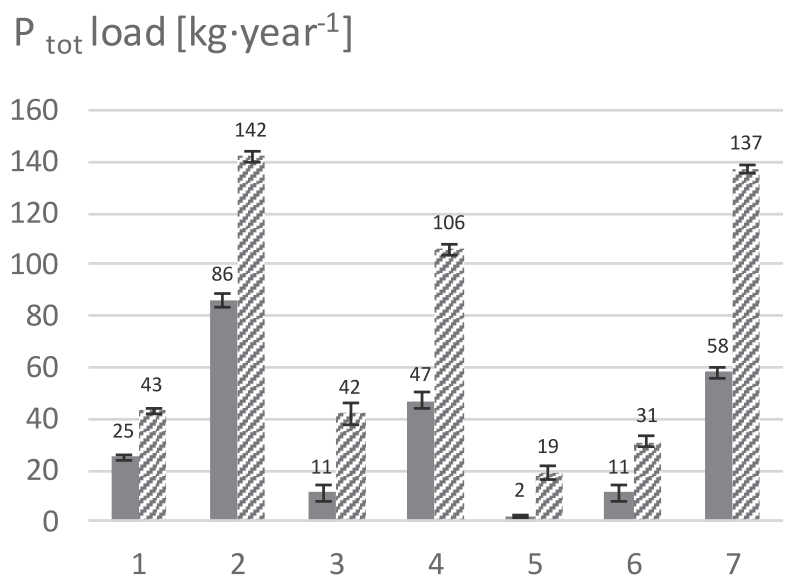

Hydrological summer $\approx$ Hydrological winter

\section{$\mathrm{P}-\mathrm{PO}_{4}$ load $\left[\mathrm{kg} \cdot\right.$ year $\left.^{-1}\right]$}

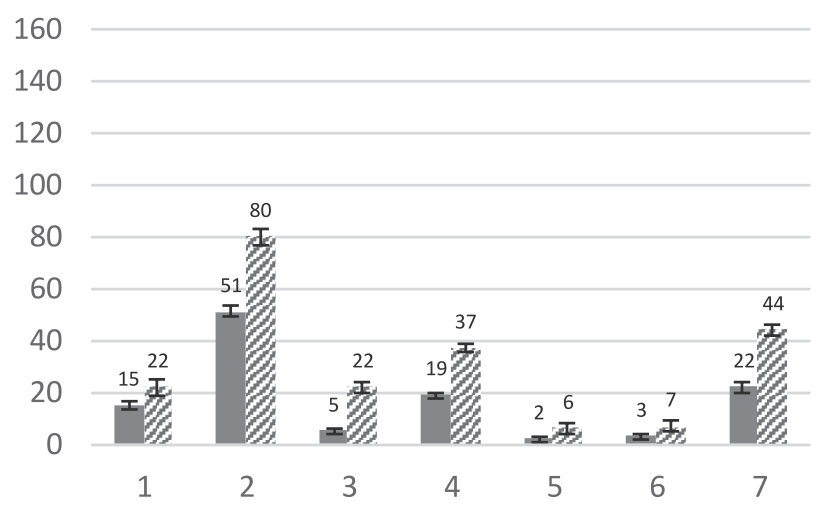

- Hydrological summer $\quad \boldsymbol{Z}$ Hydrological winter

Fig. 4. Loads of $\mathrm{P}_{\text {tot }}$ and $\mathrm{P}_{-} \mathrm{PO}_{4}$ in the waters of Sząbruk stream, which carried impurities from agricultural areas, after discharge of sewage from the treatment plant was discontinued. 1, 2, 3, 4, 5, 6, 7 - study sites as in Table 6.

the value corresponding to the inflow from the forest watershed $(0.16 \mathrm{mg} / \mathrm{L})$, whereas the phosphate reduction was 4 times greater than the inflow from the stream. Greater reduction was achieved during the period of hydrological summer as compared to the remaining part of the hydrological year.

At that time, water from Sząbruk stream contained $0.29 \mathrm{mg} / \mathrm{L}$ of phosphorus after flowing through the surrounding ditch, including $0.32 \mathrm{mg} / \mathrm{L}$ during the hydrological winter and $0.24 \mathrm{mg} / \mathrm{L}$ in summer. The concentration of total phosphorus increased compared to the inflow from Sząbruk stream from the agricultural area, drained by the drainage system. This is associated to the release of phosphorus accumulated in deposits during the period of sewage discharge. A decrease to the level of $0.11 \mathrm{mg} / \mathrm{L}$ was recorded for phosphates. The mixing of water outflowing from the constructed wetland and the surrounding ditch resulted in the inflow of $0.25 \mathrm{mg} / \mathrm{L} \mathrm{P}_{\text {tot }}$ and $0.09 \mathrm{mg} \mathrm{P}_{-} \mathrm{PO}_{4} \mathrm{~L}$ to Lake Wulpińskie, the concentrations being lower by $17 \%$ (total phosphorus) and by $63 \%$ (phosphates) as compared to the concentrations recorded during the period of the sewage discharge. Lower concentrations of phosphorus and phosphates in the water of the

Table 7. Balance of nutrients inflowing to the lake from Sząbruk stream watershed after sewage discharge from the treatment plant was discontinued.

\begin{tabular}{|c|c|c|c|c|c|c|}
\hline & Item & Stream & $\begin{array}{c}\text { Drainage } \\
\text { system }\end{array}$ & $\begin{array}{l}\text { Inflow to Lake } \\
\text { Wulpińskie }\end{array}$ & $\begin{array}{l}\text { Difference (reduction in } \\
\text { the wetland) }\end{array}$ & $\%$ reduction \\
\hline \multicolumn{7}{|c|}{$\mathrm{P}_{\text {tot }}$ load, $\mathrm{kg} \cdot$ year $^{-1}$} \\
\hline \multirow{2}{*}{$\begin{array}{l}\text { Hydrological } \\
\text { year }\end{array}$} & Without the wetland & $228 * \pm 3 * *$ & $74 \pm 1$ & $302 \pm 2$ & \multirow{2}{*}{107} & \multirow{2}{*}{35} \\
\hline & Including the wetland & $228 \pm 3$ & $74 \pm 2$ & $195 \pm 2$ & & \\
\hline \multirow{2}{*}{$\begin{array}{l}\text { Hydrological } \\
\text { winter }\end{array}$} & Without the wetland & $142 \pm 2$ & $61 \pm 0$ & $203 \pm 2$ & \multirow{2}{*}{66} & \multirow{2}{*}{32} \\
\hline & Including the wetland & $142 \pm 1$ & $61 \pm 4$ & $137 \pm 3$ & & \\
\hline \multirow{2}{*}{$\begin{array}{l}\text { Hydrological } \\
\text { summer }\end{array}$} & Without the wetland & $86 \pm 2$ & $13 \pm 2$ & $99 \pm 1$ & \multirow{2}{*}{41} & \multirow{2}{*}{41} \\
\hline & Including the wetland & $86 \pm 2$ & $13 \pm 2$ & $58 \pm 3$ & & \\
\hline \multicolumn{7}{|c|}{$\mathrm{P}-\mathrm{PO}_{4}$ load, $\mathrm{kg} \cdot \mathrm{year}^{-1}$} \\
\hline \multirow{2}{*}{$\begin{array}{l}\text { Hydrological } \\
\text { year }\end{array}$} & Without the wetland & $131 \pm 2$ & $35 \pm 2$ & $166 \pm 2$ & \multirow{2}{*}{100} & \multirow{2}{*}{60} \\
\hline & Including the wetland & $131 \pm 2$ & $35 \pm 0$ & $66 \pm 3$ & & \\
\hline \multirow{2}{*}{$\begin{array}{l}\text { Hydrological } \\
\text { winter }\end{array}$} & Without the wetland & $80 \pm 2$ & $26 \pm 2$ & $108 \pm 2$ & \multirow{2}{*}{64} & \multirow{2}{*}{59} \\
\hline & Including the wetland & $80 \pm 3$ & $16 \pm 3$ & $44 \pm 3$ & & \\
\hline \multirow{2}{*}{$\begin{array}{l}\text { Hydrological } \\
\text { summer }\end{array}$} & Without the wetland & $51 \pm 2$ & $7 \pm 2$ & $58 \pm 2$ & \multirow{2}{*}{36} & \multirow{2}{*}{62} \\
\hline & Including the wetland & $51 \pm 2$ & $7 \pm 1$ & $22 \pm 3$ & & \\
\hline
\end{tabular}

$*$ average, $* * \pm \mathrm{SD}$ 
object under study should be attributed to a significant contribution of sorption.

A specification of the phosphorus load revealed that in the section from the source to the site above the constructed wetland, the waters of Sząbruk stream carried $228 \mathrm{~kg} \mathrm{P}_{\text {tot }} \cdot$ year $^{-1}$, including $131 \mathrm{~kg} \mathrm{P}-\mathrm{PO}_{4} \cdot$ year $^{-1}$ on average (Fig. 4). The load outflowing from the forest was $68 \mathrm{~kg} \mathrm{\textrm {P } _ { \text { tot } }}$.year ${ }^{-1}$, including $37 \mathrm{~kg} \mathrm{P}_{-} \mathrm{PO}_{4} \cdot$ year $^{-1}$. The agricultural watershed supplied $160 \mathrm{~kg} \mathrm{P}_{\text {tot }}$. year $^{-1}$, including $94 \mathrm{~kg} \mathrm{P}_{-} \mathrm{PO}_{4}$ :year-1. Inflow from watershed unit areas was similar to that recorded in previous years.

On average, $160 \mathrm{~kg}$ of phosphorus flowed into the constructed wetland during the period under study, which means that the unit load of inflowing contamination was $0.57 \mathrm{~g} / \mathrm{m}$. According to the Vollenweider criterion [25], the wetland was still under threat of degradation. $42 \mathrm{~kg} \mathrm{P}_{\text {tot }} \cdot$ year $^{-1}$ including $10 \mathrm{~kg}$ $\mathrm{P}_{-} \mathrm{PO}_{4}$.year ${ }^{-1}$ flowed out of the constructed wetland.

Outflow of the system consisting of the surrounding ditch and the constructed wetland, $195 \mathrm{~kg} \mathrm{P}_{\text {tot }} \cdot$ year $^{-1}$, including $66 \mathrm{~kg} \quad \mathrm{P}_{-} \mathrm{PO}_{4} \cdot$ year $^{-1}$ flowed into Lake Wulpińskie; unit inflow amounted to $0.15 \mathrm{~kg} / \mathrm{ha}$ year $^{-1}$ and $0.05 \mathrm{~kg} / \mathrm{h} \cdot$ year $^{-1}$, respectively (Fig. 4). Specifications show that the wetland and the surrounding ditch reduced the load by $107 \mathrm{~kg} \mathrm{P}_{\text {tot }}$.year ${ }^{-1}$ (reduction by 35\%), including phosphates at $100 \mathrm{~kg} \mathrm{P}-\mathrm{PO}_{4} \cdot \mathrm{year}^{-1}$ (reduction by $60 \%$ ) (Table 7 ). Measurements taken after the period of sewage discharge show that the wetland still acts as a phosphorus-intercepting barrier, with much lower extent of total phosphorus load reduction as compared to the inflow. The amount of phosphorus in the wetland was considerably affected by its concentration in the inflowing water, whereas phosphorus load outflowing from the wetland was similar during both periods of the study, i.e., with a high load from sewage discharge and afterwards.

\section{Conclusions}

1. Among the sources of phosphorus inflowing to small streams, the major part is contributed by sewage discharge from small treatment plants that supply the main portion of phosphorus compounds, thereby causing the water quality to deteriorate significantly.

2. The flow of water loaded with inflowing pre-treated sewage through a constructed wetland significantly improved its quality. The average annual concentration of the examined forms of phosphorus decreased by $19 \% \mathrm{P}_{\text {tot. }}$ and by $53 \% \mathrm{P}_{-} \mathrm{PO}_{4}^{3-}$ during the period when the treatment plant was in operation, and by $36 \% \mathrm{P}_{\text {tot. }}$ and $81 \% \mathrm{P}^{-} \mathrm{PO}_{4}{ }^{3-}$ after the sewage discharge from it had stopped.

3. The phosphorus load in the watershed under study was effectively reduced. The average phosphorus load flowing through the wetland and the surrounding ditch was reduced by $51 \%$ for $\mathrm{P}_{\text {tot. }}$ and by $53 \%$ for $\mathrm{P}_{-} \mathrm{PO}_{4}^{3-}$ during the period when sewage was discharged from the treatment plant and by $35 \% \mathrm{P}_{\text {tot. }}$ and $60 \% \mathrm{P}_{-} \mathrm{PO}_{4}{ }^{3-}$ after that. The effect of the wetland activity can be attributed to phosphorus biosorption, as it depended on weather conditions, mainly on the temperature, and it is higher during the hydrological summer than in winter.

4. A supply of water abundant in biogenic elements led to intense growth of rush vegetation (macrophytes) with high biomass production and accumulation of phosphorus in it and in deposits.

5. The annual reduction of phosphorus load in the stream flowing through the wetland was equal to $8.5 \mathrm{~kg} \mathrm{P}$ per 1 ha of the wetland. Phosphorus accumulation throughout the period when the constructed wetland was in operation was equal to $50 \mathrm{~kg}$ in plants and $107 \mathrm{~kg}$ in deposits per 1 ha of wetland. The annual accumulation of phosphorus in deposits amounted to $4.03 \mathrm{~kg} \mathrm{P} \cdot \mathrm{ha}^{-1}$ of the wetland bottom.

\section{Acknowledgements}

Project financially supported by Minister of Science and Higher Education in the range of the program entitled "Regional Initiative of Excellence" for the years 2019-2022, Project No. 010/RID/2018/19, amount of funding 12.000.000 PLN.

\section{Conflicts of Interest}

The authors declare no conflict of interest.

\section{References}

1. POTASZNIK A., SZYMCZYK S., SIDORUK M., ŚWITAJSKA I.J. Role of Lake Symsar in the reduction of phosphorus concentration in surface runoff from agricultural lands. Journal of Water and Land Development 20 (1), 39, 2014.

2. JORDAN P., MELLAND A.R., MELLANDER P.E., SHORTLE G., WALL D. The seasonality of phosphorus transfers from land to water: implications for trophic impacts and policy evaluation. Science of the Total Environment, 434, 101, 2012.

3. JOHNSTON C.A., BROWN T.N. Water chemistry distinguishes wetland plant communities of the Great Lakes coast. Aquatic botany, 104, 111, 2013.

4. JOHNSTON C.A., ZEDLER J.B. Identifying preferential associates to initiate restoration plantings. Restoration Ecology, 20 (6), 764, 2012.

5. SCHINDLER D.W., CARPENTER S.R., CHAPRA S.C., HECKY R.E., ORIHEL D.M. Reducing phosphorus to curb lake eutrophication is a success. Environ. Sci. Technol., 50 (17), 8923, 2016.

6. SCHÖNBRUNNER I.M., PREINER S., HEIN T. Impact of drying and re-flooding of sediment on phosphorus dynamics of river-floodplain systems. Science of the total environment, 432, 329, 2012. 
7. JORDAN P., MELLAND A.R., MELLANDER P.E., SHORTLE G., WALL D. The seasonality of phosphorus transfers from land to water: implications for trophic impacts and policy evaluation. Science of the Total Environment, 434, 101, 2012.

8. GONZALEZ-SANCHIS M., MURILLO J., CABEZAS A., VERMAAT J.E., COMIN F.A., GARCIA-NAVARRO P. Modelling sediment deposition and phosphorus retention in a river floodplain. Hydrol. Process., 29 (3), 384, 2014.

9. HERMANOWICZ W., DOJLIDO J., DOŻAŃSKA W., KOZIOROWSKI B., ZERBE J. Physico-chemical analysis of water and sewage (in Polish), Arkady, 1999.

10. HERMANOWICZ W., DOJLIDO J., DOŻAŃSKA W., KOZIOROWSKI B., ZERBE J. Physico-chemical analysis of water and sewage (in Polish), Arkady, 1999.

11. COVENEY M.F., STITES D.L., LOWE E.F., BATTOE L.E., CONROW R. Nutrient removal from eutrophic lake water by wetland filtration. Ecol Eng, 19, 141, 2002.

12. HASLAM S.M., WOLSELEY P.A. River plants of western Europe. Cambridge University Press, 465, 2014.

13. TILGALIS E., GRINBERGA L. Energy-efficient wastewater treatment technologies in constructed wetlands. In Civil Engineering. International Scientific Conference. Proceedings (Latvia). Latvia University of Agriculture, 2011.

14. VOHLA C., KÕIV M., BAVOR J., CHAZARENC F., MANDER Ü. Filter materials for phosphorus removal from wastewater in treatment wetlands - A review. Ecological Engineering, 37, 70, 2011.

15. GRABIŃSKA B., KOC J., CYMES I., SZYMCZYK $S$. Changes in the middle section of the Narew River (between Ostrołęka and Łomża) in view of natural factors and anthropogenic pressures. Journal of Ecological Engineering, 15 (2), 25, 2014.

16. FERN'ANDEZ-ALAEZ M., FERNANDEZ-ALAEZ C., BÈCARES E. Nutrient content in macrophytes in Spanish shallow lakes. Hydrobiologia, 408/409, 317, 1999.

17. DIOP C., DEWAELE D., CAZIER F., DIOUF A., OUDDANE B. Assessment of trace metals contamination level, bioavailability and toxicity in sediments from Dakar coast and Saint Louis estuary in Senegal, West Africa. Chemosphere, 138, 980, 2015.

18. GLIŃSKA-LEWCZUK K., SKWIERAWSKI A., KOBUS SZ., SIDORUK M., KRZYŻANIAK M. Spatial Distribution of Heavy Metals in Bottom Sediments of Oxbow Lakes in northern Poland Differed by Hydrological Connectivity. Fresenius Environmental Bulletin, 18 (7), $1138,2009$.

19. OBOLEWSKI K., GLIŃSKA-LEWCZUK K. Distribution of heavy metals in bottom sediments of floodplain lakes and their parent river - a case study of the Słupia. Journal of Elementology, 18 (4), 673, 2013.

20. MADEYSKI M., TARNAWSKI M. Sedimentation process of the bottom deposits in small water reservoirs. [Przebieg procesu sedymentacji osadów dennych małych zbiorników wodnych.] Rocz. AR Poznań, Melior. Inż. Środ., 25 (357), 345, 2004.

21. KOC J., SKONIECZEK P. Concentration of trace elements in bottom sediments of a stream, a pond and a lake loaded with runoff from an agricultural catchment. Polish J. Environ. Stud., 15 (2a), Part II, 356, 2006.

22. NI Z., WANG S. Historical accumulation and environmental risk of nitrogen and phosphorus in sediments of Erhai Lake, Southwest China. Ecological Engineering, 79, 42, 2015.

23. YIN H., KONG M. Simultaneous removal of ammonium and phosphate from eutrophic waters using natural calcium-rich attapulgite-based versatile adsorbent. Desalination. 351, 128, 2014.

24. WANG L., GAN H., WANG F., SUN X., ZHU Q. Characteristic analysis of plants for the removal of nutrients from a constructed wetland using reclaimed water. CLEAN-Soil, Air, Water, 38 (1), 35, 2010.

25. VOLLENWEIDER R.A. Scientific fundamentals of the eutrophication of lakes and flowing waters, with particular reference to nitrogen and phosphorus as factors in eutrophication. DAS/CSIO/68.27. OECD, Paris, 192, 1968. 